\begin{tabular}{|c|c|c|c|c|c|c|}
\hline \multirow{4}{*}{ Impact Factor: } & ISRA (India) & $=3.117$ & SIS (USA) & $=0.912$ & ICV (Poland) & $=6.630$ \\
\hline & ISI (Dubai, UAE & $=0.829$ & РИНЦ (Russia) & $=0.156$ & PIF (India) & $=1.940$ \\
\hline & GIF (Australia) & $=0.564$ & ESJI (KZ) & $=8.716$ & IBI (India) & $=4.260$ \\
\hline & JIF & $=1.500$ & SJIF (Morocco) & $=5.667$ & OAJI (USA) & $=0.350$ \\
\hline
\end{tabular}

\section{SOI: 1.1/TAS DOI: 10.15863/TAS International Scientific Journal Theoretical \& Applied Science}

p-ISSN: 2308-4944 (print) e-ISSN: 2409-0085 (online)

Year: 2019 Issue: $05 \quad$ Volume: 73

Published: $30.05 .2019 \quad$ http://T-Science.org

SECTION 29. Literature. Folklore. Translation Studies.

UDK 808.5
QR - Issue
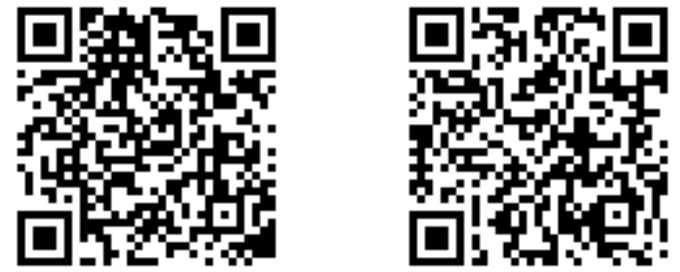

Shaxnoza Baxtiyorovna Sagatova teacher,

Tashkent State Technical University named after Islam

Karimov

Diyora Toxirovna Pardayeva teacher,

Tashkent State Technical University named after Islam Karimov

\title{
LANGUAGE GAME IN THE ARTISTIC TEXT: PROBLEMS AND TASKS
}

Abstract: Language play is a certain type of speech behavior of speakers, based on deliberate (conscious, thoughtful) violation of the system relations of language, i.e. on the destruction of speech norms in order to create non-canonical language forms and structures that acquire expressive meaning as a result of this destruction and the ability to cause aesthetic and, in General, stylistic effect in the listener/reader. This article highlights the actual problems in linguistics language game in the literary text: problems and problems.

Key words: language game, artistic text, linguistics, stylistics, structure, speech norms, expressive meaning.

Language: English

Citation: Sagatova, S. B., \& Pardayeva, D. T. (2019). Language game in the artistic text: problems and tasks ISJ Theoretical \& Applied Science, 05 (73), 630-633.

Soi: http://s-o-i.org/1.1/TAS-05-73-98 Doi: crossef https://dx.doi.org/10.15863/TAS.2019.05.73.98

\section{Introduction}

In modern linguistics, interest in the manifestations of the creative function of language, one of which is the language game, has significantly increased. In this regard, the study of a literary text with a high degree of linguistic conditionality is particularly relevant, the distinctive feature of which is the author's focus on the intentional modeling of semantic, lexical, syntactic, word-formation, pragmatic anomalies. The latter help to realize inherent in the system of language and reflected in speech inconsistency and ambiguity of the functioning of language units.

Experimental anomalies act as an artistic language experiment of the author and create prerequisites for the inclusion of the literary text receptor in the language game. The complexity of the phenomenon of language game determines the ambiguity of approaches to the interpretation of its essence, mechanisms, philosophical, psychological, social, aesthetic and linguistic nature. Turning to the issue of the possibility of translation of language play from one language to another due to the desire of linguists to investigate the problem of the author's individual word creation, derogations from the language of the Canon, field rules and antinomy in the language.

The present study is devoted to the comparative analysis of the language game in the literary text on the material of English, Russian and Uzbek languages.

\section{Materials and Methods}

The beginning of the development of the theory of the game is usually associated with the names of such scientists of the nineteenth century, as F.Schiller, H.Spencer, W.Wundt. In developing their philosophical, psychological and mainly aesthetic views, they are only simultaneously in several positions, and touched the games as one of the most common phenomena of life, linking the origin of the game with the origin of art.

In the works of E.Hazing presented the concept of the game as the original form of human activity. His research led him to realize the relationship between play and art as activities with a common genetic basis. E. hazinga also came to the conclusion about the universality of the game principle in culture, which extends to various spheres of human activity. Language is seen as an object, outdoor games for impact. 


\begin{tabular}{|c|c|c|c|c|c|c|}
\hline \multirow{4}{*}{ Impact Factor: } & ISRA (India) & $=3.117$ & SIS (USA) & $=0.912$ & ICV (Poland) & $=6.630$ \\
\hline & ISI (Dubai, UAI & $=0.829$ & РИНЦ (Russia & $=0.156$ & PIF (India) & $=1.940$ \\
\hline & GIF (Australia) & $=0.564$ & ESJI (KZ) & $=8.716$ & IBI (India) & $=4.260$ \\
\hline & JIF & $=1.500$ & SJIF (Morocco & $=5.667$ & OAJI (USA) & $=0.350$ \\
\hline
\end{tabular}

Currently, there are different directions in the study of the phenomenon of the game. The game is the object of research of many Sciences. In pedagogy, the game is considered from the position of influence on the development of creative potential and the ability to integrate the individual into society (L.S.Vygotsky, J.Piaget, D.B.Elkonin, etc.). Psychologists study the game as a component of personality behavior in various situations (reflexive, role-playing games E.Bern, I.S.Kohn, etc.). Sociological concepts connect the phenomenon of the game with the functioning of a person in certain roles that he plays in life (I.Hoffman, Y.Levada, R.Lipton, George.). An integral object of the study is the game and the study of dramatic art (H. Logman, V. Meyerhold, K. S. Stanislavsky and others). The philosophical and cultural works analyze the role of the game in society, its importance in the development of culture, the ratio of categories of Play and Being (XX. Gadamer, Yu. M. Lotman, L. T. Retyunskikh, J. Hazing, etc.).

The theoretical study of the language game foreign linguistics has a long tradition. The problem began to be developed in the aspects of linguistic norm and anomaly, linguistic experiment, verbal creativity of the author, linguistic and creative speech activity in the 80-90 years of the 20th century in the works of Y.D.Apresyan, N.D. Harutyunova, T.V.Bulygina, T.A.Gridina, A.D.Shmeleva, E.A.Zemskaya, E.V.Paducheva, B.Yu.Norman, V.3. Sannikova, O.Aksenova. Despite the urgency of the problem within the framework of the modern text-centric paradigm, there is a lack of research carried out in the comparative aspect, which analyzes the possibility of recreating the author's language game by means of the translation language.

Language game is a term in which different authors do not put quite the same content. This is explained by the complexity of the phenomenon itself, since "the diversity of the language game makes it difficult to define it consistently and comprehensively." In modern researchers, this term is understood primarily as a manifestation of a person's creative attitude to language, a conscious destruction of the language norm by the individual. it is a set of "the most stable traditional implementations of the language system, selected and fixed in the process of public communication." Most often with the expression in the speech of comic meanings or the desire to create a "fresh, new image." Characterized mainly, public and an artist styles of speech.

The term "language game", introduced into linguistics by L.Wittgenstein, denotes the specific use of language units, conscious of the speaker in functional terms, i.e. correlated with the sphere of communication. Language game is associated with the activity of the linguistic personality and the ability to creatively use language knowledge.

Understanding of language game outside of creative activity is impossible, because:
1) the ability of the subject to a bright, unusual, effective use of the word (or expression) is always secondary to the knowledge of the language system and the possession of its normative connections, i.e. the ability to "play with the word" involves the possession of the stylistic aspect of language;

2) "game" moment in speech communication can appear only when the speaker carries out a purposeful search for methods of destruction of conventional language structures and related stereotypes of speech perception;

3) Language game it is always targeted: being purposeful and thought out as a spectacular variant of language use, it cannot take place as such without understanding it by the addressee;

4) Language game is always aimed at creating a new meaning in the language (speech) structure, unfamiliar to the listener/reader.

Language game is one of the many stylistic variants of implementation of the task (see), which is planned and carried out the speaker to achieve a particular stylistic effect is a stylistic component of the structure of a communicative act, or "language usage and stylistic features of the complex": stylistic task stylistic meaning - stylistic effect. Within the framework of speech usage, stylistic meaning (see) serves as a link uniting this opposition on the basis of cause-and-effect relationship.

The criterion of differentiation of the facts of Language game and speech errors is the linguistic and - wider - stylistic competence of the speaker. In contrast to the speech errors Language game is built thanks to the knowledge of the system of language relations and knowledge of stylistic patterns of use of units of language, as well as taking into account the specifics of the genre of speech production. Language game has a double orientation: it is a linguistic and speech phenomenon, because for the realization of Language game of paramount importance is the ability to creatively break (rebuild) the learned models of the standard use of language; cf. the famous line A.S.Pushkin: "No grammatical mistakes, I do not like Russian speech". In this regard, we can say that language game - a phenomenon of functional and stylistic (see).

The effect of Language game is based on the associative potential of the word - associative valence of the word, allowing variation when combining its plan of expression and plan of content and - as a result - a different interpretation of its meaning[1]. In the context, one or another particular associative valence of a word is realized - phonetic, semantic, lexical, word-formation, syntactic. Each of these particular valences acts as one or another mechanism of the Language game in Addition, the associative nature of the Language game indicates that an important means of its creation in speech is a metaphor (see Stylistic resources vocabulary, or lexical style). 


\begin{tabular}{|c|c|c|c|c|c|c|}
\hline \multirow{4}{*}{ Impact Factor: } & ISRA (India) & $=3.117$ & SIS (USA) & $=0.912$ & ICV (Poland) & $=6.630$ \\
\hline & ISI (Dubai, UAI & $=0.829$ & РИНЦ (Russia & $=0.156$ & PIF (India) & $=1.940$ \\
\hline & GIF (Australia) & $=0.564$ & ESJI (KZ) & $=8.716$ & IBI (India) & $=4.260$ \\
\hline & JIF & $=1.500$ & SJIF (Morocco & $=5.667$ & OAJI (USA) & $=0.350$ \\
\hline
\end{tabular}

At the phonetic level, language game is realized with the help of such techniques as anagram, palindrome, onomatopoeia, sound symbolism, as well as various phonosemantic convergence of words. Ex.: anagram (a statement characterized by the identity of the sound composition of the lexemes with the difference of compatibility and sequence of phonemes) - In the yard grass, on the grass firewood; Buy a pile of peak; Sasha was on the highway and sucked drying, etc.; palindrome (preserving the same meaning of the word/phrase when reading from left to right and right to left) - Ass looking for mother-inporridge; And rose fell on the paw of Azor; homophonically convergence of words (the effect of "oleshki" based on moronicism perenaznachenie words in the flow of speech) - Grandma finish the tale to his grandson: "they live happily ever after". Hearing him, the grandson asked, "Grandma, what are they chewed dobrana?"Buy me meringue! - Why, are you without Bizet's Carmen; etc.; homonymic convergence of words (the discrepancy between values of matched words based on homonyms) When a boy is called a woman's name? - When he's a heavy sleeper; Which city flies? - Eagle; "You, Petka, that write?"Opera, Vasily Ivanovich." - What kind of Opera?!" (joke); Sorry ask - associative replacement Rus. "forgiveness" on Franz. "pardon"; the foreign car "Grand sugaree" jokingly called as the wide-wide ('grand' - translated from English. 'big, huge' and 'sugare' appears here as a phonetic analogue of the Rus. 'wide'); Builder - associative Association of values 'man working on a construction site' and 'loving to drink for three, build'; rabbit - swimmer, specializing in swimming crawl; Carmen in the meaning of 'driver' (the result of the connection English. car - 'car' and man - 'man'), etc.; aronimink convergence of words (a shift in the evaluation of the qualifications referred to, identifying valuation paradox) - Grabbing (i.e. an Association of different values when thinking about privatization as the desire to grab, to steal, to assign); calendar (instead of 'calendar' by emphasizing his comic, humorous); the Squabbles of champagne (instead of 'squirt'); the Ravings of the Governor (instead of 'weekdays'); deciphering abbreviations, OOO as a 'Society with unlimited irresponsibility' (instead of 'limited liability company'), etc.

On the morphological level of Language game based on a conscious violation of the phonomorphological perception of lexical units, eg.: The adversary - the 'leftovers soup'; papazol - 'sober father,' badger 'bar for dogs'; Muzykivka wave 'youth music wave'; "Komsomolskaya Pravda!"; Eldoradio from 'Eldorado', etc.
At the lexical level, Language game is created due to the discrepancy between the semantic content of the motivating and motivated foundations in the act of word formation, for example. Again already stagnatilis!; Here in town it is quite asintelligence; Obychayny case (from the 'extraordinary incident'); Sultoprida newspaper (from the 'yellow press'); Resembelence apartments ('fashionable'), etc.

\section{Conclusion}

In addition, Language game is implemented in the statement by means of restructuring syntactic relations, when the key tool for creating a "new image" is the context and the potential variation of the semantics of words, phrases, and semantic relations between parts of the sentence. In the latter case, Language game creates "the effect of deceived expectation": the meaning of the phrase predicted by the recipient is destroyed by atypical (unexpected) word order or the introduction of lexical components atypical for this syntactic construction. Ex.: I will smoke, but I will not stop drinking (pun); Our man is always where it's hard. It is always difficult where our man (pun), etc.

An important property of this type of Language game is that, starting as a destruction of the sentence structure, it (Language game) turns out to be a textual phenomenon: the very fact of the game becomes clear only from the entire surrounding context or even the whole text (cf. "destructive" language of A. Platonov's texts). It is at this level that Y. I. fully realizes his activity, creative character due to the ability of "syntactically destructive" units to spread comic or satirical meaning to a wider text space up to the creation of a special artistic concept. As textual means of Language game are often different kinds of puns, polysemantic lexemes, the exact meaning of which (most often atypical for them) is clarified only by the surrounding context, as well as special, conceptually thought out by the author cases of violation of normative syntactic relations. Eg.: Why are your berries green? - Because they are still green (pun); On the table we usually had a snack like "I beg you" (V. Erofeev); Yesterday, thus, gradually brightened - in the sense of 'in the murky and viscous hangover consciousness of Stepa Likhodeev clarified the events of yesterday' (Bulgakov); an Elderly friend makes us lie on the issue of the necessary shame for the government; Dvanov did not know where to think (A. Platonov), etc.

Language play as a "reproduction" of colloquial speech or individual-stylistic experiment can be considered on the example of the reception of sound repetition in a prosaic literary text 


\begin{tabular}{llllll} 
& ISRA (India) $=\mathbf{3 . 1 1 7}$ & SIS (USA) $=\mathbf{0 . 9 1 2}$ & ICV (Poland) & $\mathbf{= 6 . 6 3 0}$ \\
Impact Factor: & ISI (Dubai, UAE) $=\mathbf{0 . 8 2 9}$ & PUHЦ (Russia) $=\mathbf{0 . 1 5 6}$ & PIF (India) & $=\mathbf{1 . 9 4 0}$ \\
& GIF (Australia) $=\mathbf{0 . 5 6 4}$ & ESJI (KZ) & $\mathbf{8 . 7 1 6}$ & IBI (India) & $=\mathbf{4 . 2 6 0}$ \\
& JIF & $\mathbf{1 . 5 0 0}$ & SJIF (Morocco) $=\mathbf{5 . 6 6 7}$ & OAJI (USA) & $\mathbf{0 . 3 5 0}$ \\
\hline
\end{tabular}

\section{References:}

1. Vinokur, T. G. (1980). Zakonomernosti stilisticheskogo ispol'zovaniya yazykovykh edinits. Moscow.

2. Vitgenshteyn, L. (1985). Filosofskie issledovaniya // Novoe v zarubezhnoy lingvistike. Vyp. XVI. Moscow.

3. Uvarova, N. L. (1986). Logiko-semanticheskie tipy yazykovoy igry (na materiale angliyskoy dialogicheskoy rechi). Avtoref. dis. ... kand. filol. nauk. Gor'kiy.

4. Arutyunova, N. D. (1987). Nenormativnye yavleniya i yazyk. Yazyk i logicheskaya teoriya. Moscow.

5. Norman, B. Y. (1987). Yazyk: znakomyy neznakomets. Minsk.
6. Teliya, V. N. (1988). Metafora kak model' slovoproizvodstva $i$ ee ekspressivnootsenochnaya funktsiya. Metafora v yazyke i tekste. Moscow.

7. Fuko, B. (1990). Lingvisticheskie struktury, porozhdaemye igroy slov. $R Z h$ "Obshchestvennye nauki za rubezhom. Yazykoznanie", №6.

8. Gridina, T. A. (1996). Yazykovaya igra: stereotip i tvorchestvo. Ekaterinburg.

9. Zemskaya, E. A., Kitaygorodskaya, M. A., Rozanova, N. N. (1983). Yazykovaya igra. Russkaya razgovornaya rech'. Moscow.

10. Karl-Otto, Appel' (1989). Transformatsiya filosofii. p. 86. 